\title{
Relationship of early laying, number and weight of laid eggs to fertility and hatchability of eggs in initial laying lines of hens
}

\author{
LADISLAV MÁCHAL' ${ }^{1}$ LUCIE ŠVÁBOVÁ ${ }^{1}$, LIBOR SEVERA² and RADEK FILIPČÍK' ${ }^{1}$ \\ ${ }^{1}$ Department of Animal Breeding, ${ }^{2}$ Department of Engineering, Mendel University of Agriculture and Forestry in \\ Brno, Czech Republic
}

\section{Abstract}

The relationships between age of hens, number of laid eggs, egg weight on one hand and fertility and hatchability on the other were analysed during two periods of individual pedigree hatching. Altogether 1369 hens originated from 9 selected initial laying lines of Bar Plymouth Rock (BPR) (3 lines), Rhode Island Red (RIR) (4 lines), Rhode Island White (RIW), and Sussex Light (SUL) breeds. A total number of 23473 eggs from hens of all 9 aforementioned lines were set after being artificially inseminated. The total average hatchability of set eggs was $73.2 \%$ and the average percentage of unfertilised eggs was $9.3 \%$. Positive correlations $\left(r_{p}=0.22\right.$ to $\left.r_{p}=0.72 ; P<0.01\right)$ were found between the total number of eggs laid till the 240th day of age and the number of eggs produced at the beginning of the laying period in the all studied lines. There were negative correlations $\left(r_{p}=-0.03\right.$ to $\left.r_{p}=-0.16 ; P<0.01\right)$ between the total number of eggs laid till the 240th day of age and the average egg weight (on the 222nd day of age). Zero to positive correlations existed between the total number of eggs laid till the 240th day of age on one hand and the number of hatching eggs, number of hatched chicks/hen and hatchability; the calculated values ranged from $r_{p}=-0.02$ to $r_{p}=0.30(P<0.01)$, from $r_{p}=-0.08$ to $r_{p}=0.36 \quad(P<0.01)$, and from $r_{p}=-0.09$ to $r_{p}=0.30 \quad(P<0.01)$, respectively. Correlations between the egg weight and number of hatched chicks/hen were negative to zero and their values ranged from $r_{p}=-0.19(P<0.01)$ to $r_{p}=0.02$. Correlations between the egg weight and hatchability were always negative $\left(r_{p}=-0.15 ; P<0.05\right.$ to $\left.r_{p}=-0.04\right)$. Regarding the fact that there is a concurrent selection for an increased egg weight it can be said that this preference of smaller eggs is really counter-productive. A positive relationship between the number of hatching eggs/hen and the hatchability $\left(r_{p}=-0.02\right.$ to $\left.r_{p}=0.39 ; P<0.01\right)$ was influenced by calculated negative correlations existing between the weight of eggs and the hatchability as well as between the weight of eggs and the number of laid eggs. As far as the hatchability is concerned, it can be concluded that in the aforementioned laying lines those hens are preferred, which produce more eggs of smaller size and that this fact obviously influences also the efficiency of selection for a greater weight of produced eggs.

Keywords: laying hens lines, egg weight, egg production, fertility, hatchability 


\section{Zusammenfassung}

\section{Beziehungen zwischen frühem Legen, der Eizahl und -masse zur Befruchtung und den Brutergebnissen von Hennen von neun Ausgangslinien}

In zwei Parallelbraten mit 1369 Legehennen aus neun Ausgangslinien (drei Linien Bar Plymouth Rock [BPR], vier Linien Rhode Island Red [RIR], eine Linie Rhode Island White [RIW] und eine Linie Sussex Light [SUL]) wurden die Beziehungen zwischen frühen Legebeginn, der Eizahl und -masse zur Befruchtung und den Schlupfgebnissen untersucht. Nach der Besamung der Legehennen wurden insgesamt 23473 Eier bebrütet. Die Brutergebnisse aller Eier lagen bei $73,2 \%$ und der durchschnittliche Anteil unbefruchtete Eier bei 9,2\%. Positive Korrelationen zwischen der Anzahl der Eier, die bis zum 240. Tag gelegt wurden, und der Eizahl gelegt bis zum 150. bzw. 240. Tag lagen bei allen neun Linien signifikant zwischen $r_{p}=0,22$ bis 0,72 . Negative Beziehungen fanden sich zwischen der Gesamteizahl bis zum 240. Tag und dem Durchschnittseigewicht am 222. Lebenstag von $r_{p}=-0,03$ bis $-0,16$. Keine bis positive Korrelationen ergaben sich zwischen der Gesamteizahl und der Bruteizahl $\left(r_{p}=-0,02\right.$ bis 0,30$)$, der Gesamteizahl und der Anzahl geschlüpfter Kücken $\left(r_{p}=-0,08\right.$ bis 0,36$)$ sowie der Gesamteizahl und den Brutergebnissen $\left(r_{p}=-0,09\right.$ bis 0,30$)$. Während die Beziehungen zwischen den Eigewichten und der Zahl geschlüpfter Kücken meist negativ waren $\left(r_{p}=-019\right.$ bis 0,02$)$, erwiesen sie sich zu den Brutergebnissen stets als negativ $\left(r_{p}=-0,15\right.$ bis $\left.-0,04\right)$. Sämtliche hier dargestellten Korrelationskoeffizienten waren signifikant. In allen neun Linien erbrachten kleinere Eier bessere Brutergebnisse, was kontraproduktiv zu den Selektionsbestrebungen nach höheren Eigewichten steht. Korrelationen zwischen der Gesamtzahl an Brateiern je Henne und den Schlupfergebnissen waren positiv, was vermutlich durch die negativen Beziehungen der Eigewichte beeinflusst wurde.

Schlüsselwörter: Legehenne, Linie, Eigewicht, Legeleistung, Befruchtung, Schlupfergebnisse

\section{Introduction}

Fertility and hatchability of eggs is influenced by a number of both exogenous and endogenous factors. Among them, not only the hatching technology but also various factors influencing the biological value of eggs may be classified as very important. The basic biological factors are as follows: nutrition of both, hens and cocks, health condition of hens, breed and line of hens, weight and composition of eggs, storage of eggs and some other. A little consideration was paid to hatchability in the breeding programs until now (FLOCK 1995).

FASENKO et al. (2000) studied the effect of the relationship existing between the hen's age and egg fertility and the effect of age and the sequence of the laid egg in the series on the fertility, hatchability, viability and embryonic development. In accordance with data published by O'SULLIVAN et al. (1991) they also reported that both fertility and hatchability of eggs were significantly dependent on hen's age because eggs laid by older hens showed decreased fertility and hatchability. Also TONA et al. (2001), mention that the age of broiler breeders is an important parameter, which should be taken into 
account by the hatchery managers. Eggs produced by either young or old breeders do not hatch as well as eggs originating from the breeders in the age of 40 to 42 weeks. The effect of egg size on hatchability was emphasised by WILSON (1991) who mentioned that hatchability of eggs of medium size was better than that of very large or very small ones.

PEDROSO et al. (2005) obtained similar results; these authors mentioned that as the age of breeders advanced, characteristics related to egg fertility and hatchability gradually improved. The effect of age of breeders on hatchability was observed also by RUIZ and LUNAM (2002) who wrote that fertilised eggs stored at higher temperatures showed a reduced hatchability of fertile eggs. SEKER et al. (2005) found significant effects between pre-incubation storage and egg weight on hatching results of Japanese quail eggs. Hatchability is influenced by some internal factors, such as genotype of hatching chicks and presence of lethal and/or semi-lethal factors. Also egg weight (SEWALEM and WILHELMSON 1999), yolk/albumin ratio (MÁCHAL et al. 1992), and occurrence of double yolk eggs (FASENKO et al. 2000) are important. HARTMANN et al. (2002) calculated for hens of a White Leghorn breed line that the genetic correlation between hatchability and egg weight was $r=-0.22$.

The effect of an intensive selection (carried out on the base of major performance traits) on the reproductive capacity of hen population is a factor, which has been discussed for a very long period. DURMUS et al. (2004), for example, described connections between the concentration of zinc in the diet to some hatchability traits. If the environmental conditions are maintained, this effect is not very important. SZWACZKOWSKI et al. (2000) concluded that selection for egg production did not lead to a decrease in fertility and hatchability within a population of laying hens. Similarly, MENNICKEN et al. (2005) did not find out any significant effects of selection on fertility and hatchability; these authors performed divergent selection for the ratio of omega 3 : omega 6 polyunsaturated fatty acid in different quail lines. In the initial lines of breeders with a higher degree of homozygosity and an increased coefficient of inbreeding, the hatchability was permanently lower than that of final hybrids. MÁCHAL et al. (2003) found out that in seven initial lines of laying hens the values of average hatchability, proportion of unfertilised eggs, and embryonal mortality were equal to $71.5 \%, 11.3 \%$, and $17.2 \%$, respectively.

\section{Material and methods}

The relationship of hen age, number of laid eggs and egg weight to fertility and hatchability was analysed in nine initial laying lines of the Bar Plymouth Rock (BPR), Rhode Island Red (RIR), Rhode Island White (RIW), and Sussex Light (SUL) breeds. These hens were selected for number of laid eggs, egg weight and viability. Hens of these nine lines were individually placed in the same laying house and fed ad libitum on the same feed ration.

Altogether 1369 hens (from 6624 clinically healthy breeders kept in individual cages) were selected on the base of an analysis of results of poultry performance testing and their eggs were set for individual pedigree hatching. In the course of the first stage of individual performance testing, these selected birds were used for an analysis of 
earliness, total number of laid eggs and egg weight. The total number of laid eggs was recorded individually for each hen in all nine lines (BPR-1, BPR-2, BPR-3, RIR-4, RIR-5, RIR-6, RIR-7, RIW-8, SUL-9) within the period beginning at the moment when they were placed into cages on day 115 of their age and ending on day 240. Earliness was evaluated on the base of the number of eggs laid at the beginning of the laying period in two subsequent seasons. In the first one, the total number of produced eggs was recorded from day 115 to day 150 of age while in the other, egg production was followed from day 151 till day 175. The average weight of eggs was calculated as follows: six eggs laid in the course of the 31st week of age were weighed to obtain the arithmetic mean. The total number of weighed eggs was 8214 .

Numbers of hatching eggs, unfertilized eggs, and hatched chicks as well as the percentage of hatchability were analysed within the period of individual pedigree hatching of initial lines; this analysis concerned clinically healthy birds in the age of 48-50 weeks. After being laid, the eggs were stored in the same room under identical conditions. A total number of 23473 eggs from hens of all nine lines were set after being artificially inseminated. All defect eggs (i.e. cracks, double yolk eggs and eggs without shell) were eliminated and only intact ones were set. Incubation was carried out under identical conditions in the same setting and hatching compartments. Eggs from each hen were incubated individually. Individual hatching and marking of hatched chicks was used also within individual lines and within individual paternal and maternal families.

Tightness of the relationship between individual pairs of studied parameters (i.e. earliness, egg production, egg weight and numbers of hatching eggs, unfertilized eggs, and hatched chicks as well as the percentage of hatchability) was tested on the base of calculated phenotypic correlations using the GLM and SAS procedures.

\section{Results and discussion}

All basic parameters of earliness, egg production, egg weight and data about fertility and hatchability for all nine initial lines (i.e. 3 BPR, 4 RIR, 1 RIW, and 1 SUL line, respectively) are presented in Table 1. The average number of eggs laid by hens of all lines till the age of 150 days was $6.24 \pm 6.28$ pcs. The lowest number of laid eggs were recorded in hens of the line BPR-3 (0.41 \pm 1.09 eggs) while the highest one in hens of the line RIW-8 (11.26 \pm 5.90 eggs). Hens in the age between 151 and 175 days laid in average $11.94 \pm 3.90$ eggs; again, the lowest average number of produced eggs was recorded in the line BPR-3 (5.64 \pm 3.65 pcs) while the highest one was produced by hens of the RIR-6 line (14.01 \pm 2.06 pcs.). The average number of eggs laid by hens of all studied lines till the 240th day of age was $66.90 \pm 8.82$ pcs.; the lowest and the highest egg production was recorded in lines BPR-3 and RIR-6 (53.09 \pm 5.26 vs. $74.88 \pm 5.81$ pcs., respectively). The average weight of eggs laid by hens of all lines within the age interval of 217 and 224 days was $54.51 \pm 3.36$ g. The lowest and the highest values of egg weight were recorded in lines BPR-2 and RIR6 (i.e. $50.72 \pm 1.91 \mathrm{~g}$ vs. $57.56 \pm 3.02 \mathrm{~g}$, respectively).

Hatching eggs were collected from hens in the age of 48 to 50 weeks, thus in the second half of the laying cycle when both fertility and hatchability decreased. For older hens, a lower hatchability was observed for example also by O'SULLIVAN et al. (1991) and TONA et al. (2001). 
Table 1

Egg laying, egg weight, number of hatching eggs, unfertility and hatchability in selected original laying strains (BPR-1, BPR-2, BPR-3, RIR-4, RIR-5, RIR-6, RIR-7, RIW-8, SUL-9)

Legeleistung, Anzahl Brateier, Anzahl unbefruchteter Eier und Schlupfergebnisse in den neun Legehennenlinien (BPR-1, BPR-2, BPR-3, RIR-4, RIR-5, RIR-6, RIR-7, RIW-8, SUL-9)

\begin{tabular}{|c|c|c|c|c|c|c|c|c|c|c|}
\hline Line & Sig & & E 1-150 d & E $151-175 d$ & E $176-240 \mathrm{~d}$ & AEW 222, g & $\mathrm{HE} / \mathrm{H}, \mathrm{pcs}$. & UE/H, pcs. & $\mathrm{HC} / \mathrm{H}, \mathrm{pcs}$. & Hatchabil., \% \\
\hline \multirow{2}{*}{ BPR-1 } & \multirow{2}{*}{\multicolumn{2}{|c|}{$100 \mathrm{~A}, \mathrm{a}_{\mathrm{s}}^{\mathrm{x}}$}} & $5.11^{\text {CEFGHi }}$ & $12.64^{\mathrm{CDEFGH}}$ & $64.32^{\text {BCEFGHI }}$ & $51.27^{\text {CDEFGHI }}$ & $17.38^{\text {CGHle }}$ & $2.71^{\text {BCEFGId }}$ & $12.03^{\mathrm{Glh}}$ & $67.5^{\text {CGlbf }}$ \\
\hline & & & 4.66 & 2.68 & 6.22 & 4.66 & 2.65 & 3.51 & 4.96 & 25.8 \\
\hline \multirow{2}{*}{ BPR-2 } & \multicolumn{2}{|c|}{$251 B, b^{x}$} & $5.14^{\mathrm{CEFGHi}}$ & $13.01^{\text {CDGHef }}$ & $67.69^{A C D E F G H i}$ & $50.72^{\text {CDEFGHI }}$ & $17.20^{\text {CGHle }}$ & $1.87^{\mathrm{ABDHe}}$ & $12.77^{\mathrm{Gle}}$ & $73.4^{\mathrm{Ca}}$ \\
\hline & & $S_{x}$ & 4.70 & 2.40 & 4.95 & 1.91 & 2.68 & 2.38 & 4.00 & 19.5 \\
\hline \multirow[t]{2}{*}{ BPR-3 } & \multicolumn{2}{|l|}{$216 C_{1} C^{x}$} & $0.41^{\mathrm{ABDEFGHI}}$ & $5.64^{\mathrm{ABDEFGHI}}$ & 53.09 ABDEFGHI & $54.88^{\mathrm{ABDEFGHI}}$ & $16.11^{\mathrm{ABDFGHI}}$ & $0.89^{\mathrm{ABDHe}}$ & $12.78^{\mathrm{Gle}}$ & $78.1^{\mathrm{ABDEFH}}$ \\
\hline & & $S_{x}$ & 1.09 & 3.65 & 5.26 & 2.26 & 2.84 & 1.42 & 3.73 & 18.5 \\
\hline \multirow[t]{2}{*}{ RIR-4 } & \multicolumn{2}{|c|}{$185 \mathrm{D}, \mathrm{d}^{\mathrm{X}}$} & $4.53^{\mathrm{CEFGHI}}$ & $11.69^{A B C E F G H I}$ & $64.88^{\text {BCEFGHI }}$ & $55.91^{\mathrm{ABCFGHI}}$ & $17.09^{\mathrm{CGHI}}$ & $1.92^{\text {Clafg }}$ & $12.11^{\mathrm{GHI}}$ & $70.9^{\mathrm{CGi}}$ \\
\hline & & $\mathrm{S}_{\mathrm{x}}$ & 4.66 & 2.92 & 4.96 & 2.15 & 2.77 & 2.41 & 3.62 & 17.1 \\
\hline \multirow[t]{2}{*}{ RIR-5 } & \multicolumn{2}{|c|}{$112 \mathrm{G}, \mathrm{g}^{\mathrm{X}}$} & $9.11^{\mathrm{ABCDEI}}$ & $13.98^{\mathrm{ABCDI}}$ & $73.21^{\mathrm{ABCDIh}}$ & $57.32^{\mathrm{ABCDEF}}$ & $19.00^{\mathrm{ABCDEF}}$ & $1.11^{\mathrm{AHbd}}$ & 14.49 $\mathrm{ABCDEF}$ & $76.8^{\text {AEdh }}$ \\
\hline & & $\mathrm{S}_{\mathrm{x}}$ & 6.20 & 2.06 & 5.93 & 2.61 & 1.77 & 1.77 & 2.77 & 13.6 \\
\hline \multirow{2}{*}{ RIR-6 } & \multicolumn{2}{|c|}{$117 \mathrm{H}, \mathrm{hX}$} & $9.52^{\mathrm{ABCDEI}}$ & $14.01^{\mathrm{ABCDI}}$ & $74.88^{\mathrm{ABCDEFIg}}$ & 57.76 ${ }^{\mathrm{ABCDEF}}$ & $19.22^{\mathrm{ABCDEF}}$ & $2.44^{\mathrm{CFGle}}$ & $13.37^{\text {DEa }}$ & $70.2^{\mathrm{cgi}}$ \\
\hline & & $\mathrm{S}_{\mathrm{x}}$ & 7.50 & 2.06 & 5.81 & 3.02 & 2.89 & 3.51 & 4.18 & 20.08 \\
\hline \multirow{2}{*}{ RIR-7 } & \multirow[t]{2}{*}{203} & $x$ & $6.58^{\text {CDEFGHab }}$ & $12.97^{\text {CDGHef }}$ & $68.87^{\text {ACDEFGHb }}$ & $57.61^{\mathrm{ABCDEF}}$ & $18.58^{\mathrm{ABCDEF}}$ & $1.02^{\mathrm{ABDH}}$ & $14.38^{\mathrm{ABCDEF}}$ & 76.9 $9^{\text {AEHd }}$ \\
\hline & & $\mathrm{S}_{\mathrm{x}}$ & 6.06 & 2.75 & 6.67 & 2.64 & 3.21 & 2.15 & 4.54 & 21.1 \\
\hline \multirow[t]{2}{*}{ RIW-8 } & \multicolumn{2}{|c|}{$79 E, e^{X}$} & $11.26^{\mathrm{ABCDGHIf}}$ & $13.72^{\mathrm{ACDbi}}$ & $73.03^{\mathrm{ABCDHI}}$ & $55.78^{\mathrm{ABCFGHI}}$ & $16.59^{\text {FGHlab }}$ & $1.57^{\text {Ach }}$ & $11.69^{\mathrm{GHlbcf}}$ & $69.2^{\mathrm{CGl}}$ \\
\hline & & $S_{x}$ & 5.90 & 2.25 & 6.13 & 2.29 & 2.61 & 2.59 & 4.25 & 21.4 \\
\hline \multirow[t]{2}{*}{ SUL-9 } & \multirow{2}{*}{\multicolumn{2}{|c|}{$106 \mathrm{~F}, \mathrm{f} \underset{\mathrm{s}}{\mathrm{x}}$}} & $10.11^{\mathrm{ABCDel}}$ & $13.72^{\mathrm{ACDbi}}$ & $72.67^{A B C D H I}$ & $53.86^{\mathrm{ABCDEGHI}}$ & $17.48^{\mathrm{CEGHI}}$ & $1.32^{\mathrm{ABHd}}$ & $12.82^{\mathrm{Gle}}$ & $73.0^{\mathrm{ca}}$ \\
\hline & & & 6.57 & 2.34 & 5.55 & 2.23 & 2.51 & 2.16 & 4.25 & 21.7 \\
\hline \multirow[t]{2}{*}{ Total } & \multirow[t]{2}{*}{1369} & $x$ & 6.24 & 11.94 & 66.90 & 54.51 & 17.40 & 1.61 & 12.82 & 73.2 \\
\hline & & $S_{x}$ & 6.28 & 3.90 & 8.82 & 3.36 & 2.85 & 2.46 & 4.12 & 20.18 \\
\hline
\end{tabular}

Sig significancy, E 1-150 number of eggs laid to 150th day of age, E 151-175 number of eggs laid from 151st to 175th day of age, E 176-240 total number of eggs laid to 240th day of age, AEW 222 average egg weight 222nd day of age, $\mathrm{HE} / \mathrm{H}$ number of hatching eggs/hen, UE/H number of unfertilized eggs/hen, $\mathrm{HC} / \mathrm{H}$ number of hatched chicks/hen ${ }^{A B C D E F G H} P<0.01$, abcdetghi $P<0.05$

For incubation, altogether 23473 eggs from hens of all lines were set into the incubator; the average number of eggs was $17.40 \pm 2.85$ eggs/hen. The lowest and the highest numbers of hatching eggs per hen were recorded in lines BPR-3 and RIR-6 (16.11 \pm 2.84 vs. $19.22 \pm 2.89$ pcs., respectively). Numbers of unfertilised eggs were followed individually for each hen and their average number was $1.61 \pm 2.46$ eggs/hen (i.e. $9.3 \%$ of all eggs set into the incubator). The lowest and the highest numbers of unfertilised eggs were found out in lines BPR-3 and BPR-1 ( $0.89 \pm 1.42$ vs. $2.71 \pm 3.51$ pcs., respectively).

In the course of incubation, the average number of hatched chicks was $12.82 \pm 4.12$ per hen. The lowest and the highest average numbers of chicks hatched per hen were recorded in lines RIW-8 and RIR-5 (11.69 \pm 4.25 vs. $14.49 \pm 2.77$, respectively). The lowest and the highest percentages of average hatchability were recorded in lines BPR-1 and BPR-3 $(67.5 \pm 25.8 \%$ vs. $78.1 \pm 18.5 \%$, respectively). In all initial lines, the total average hatchability was $73.2 \pm 20.2 \%$. This average hatchability is comparable with that recorded in seven lines of breeders five generations ago, which is $71.5 \%$ (MÁCHAL et al. 2003). The average hatchability percentages found in initial lines are characteristic for homozygous populations; in hybrid combinations, however, they are always higher. It can be also concluded that values of hatchability, de facto unchanging, which were recorded after 
five generations of selection ( $71.5 \%$ and $73.2 \%$ ) are in accordance with data published by SWACZKOWSKI et al. (2000), who also did not find an effect of selection on the number of produced eggs on their fertility and hatchability. Similarly, MENNICKEN et al. (2005) did not find any negative effect of selection for the ratio of fatty acids on fertility and hatchability in quails.

The relationships existing between the total number of eggs laid to the 240th day of age on one hand and numbers produced at the beginning of the laying period, hatching and unfertilized eggs, hatched chicks, egg weight, and hatchability on the other are quantified in Table 2. These values were calculated as phenotypic correlations. Statistically highly significant phenotypic correlations $(P<0.01)$ existed between the total number of eggs laid to the 240th day of age and the number of eggs laid at beginning of the laying period in all studied lines. Phenotypic correlations existing between total number of eggs laid till the 240th day of age and the average egg weight on the 222nd day of age were always negative and ranged in individual lines from $r_{p}=-0.03$ (SUL-9) to $r_{p}=-0.16$ (lines $\mathrm{BPR}-2, \mathrm{RIR}-5$, and RIR-6). The calculated phenotypic correlations were highly significant $(P<0.01)$ for lines BPR-3 and RIR-6. The relationship between the number of set eggs and total number of eggs laid till the 240th day of age was characterised by mostly positive correlations and ranged from $r_{p}=-0.02$ (line RIR-7) to $r_{p}=0.30$ (line BPR-1). Correlations $r_{p}=0.21$ and $r_{p}=0.30$ (for lines BPR-3 and BPR- 1 , respectively) were statistically highly significant $(P<0.01)$. Zero to positive correlations existed between the total number of eggs laid to the 240th day of age and hatchability and ranged from $r_{p}=-0.09$ (line RIR-7) to $r_{p}=0.30$ (line BPR-1). Statistically highly significant positive correlations $(P<0.01)$ were calculated for lines BPR-1 $\left(r_{p}=0.30\right)$, RIR-6 $\left(r_{p}=0.23\right)$, and BPR-3 $\left(r_{p}=0.17\right)$.

Table 2

Estimation of correlation coefficient between number of eggs laid to 240 days of age and egg weight, number laid eggs in beginning of egg laying, number of hatching and unfertilized eggs, hatched chicks and hatchability

Korrelationskoeffizienten zwischen der Eizahl und den erfassten Merkmalen

\begin{tabular}{lcccccccc}
\hline Line & $\mathrm{n}$ & $\begin{array}{c}\text { Eggs } \\
0-150 \mathrm{~d}^{1}\end{array}$ & $\begin{array}{c}\text { Eggs } \\
151-175 \mathrm{~d}^{2}\end{array}$ & $\begin{array}{c}\text { AEW } \\
222 \mathrm{~d}^{3}\end{array}$ & $\begin{array}{c}\text { Hatching } \\
\text { eggs/hen }\end{array}$ & $\begin{array}{c}\text { Unfertilized } \\
\text { eggs/hen }\end{array}$ & $\begin{array}{c}\text { Hatched } \\
\text { chicks/hen }\end{array}$ & Hatchability \\
\hline BPR-1 & 100 & $0.70^{* *}$ & $0.58^{* *}$ & -0.09 & $0.30^{* *}$ & -0.08 & $0.36^{* *}$ & $0.30^{* *}$ \\
BPR-2 & 251 & $0.45^{* *}$ & $0.66^{* *}$ & $-0.16^{* *}$ & 0.10 & -0.01 & 0.07 & -0.01 \\
BPR-3 & 216 & $0.22^{* *}$ & $0.60^{* *}$ & -0.12 & $0.21^{* *}$ & $-0.16^{*}$ & $0.23^{* *}$ & $0.17^{* *}$ \\
RIR-4 & 185 & $0.58^{* *}$ & $0.50^{* *}$ & -0.05 & -0.01 & $-0.15^{* *}$ & 0.03 & 0.06 \\
RIR-5 & 79 & $0.59^{* *}$ & $0.72^{* *}$ & -0.16 & 0.11 & 0.08 & 0.11 & 0.06 \\
RIR-6 & 106 & $0.71^{* *}$ & $0.59^{* *}$ & $-0.16^{* *}$ & 0.02 & $0.27^{* *}$ & -0.08 & $0.23^{* *}$ \\
RIR-7 & 112 & $0.71^{* *}$ & $0.53^{* *}$ & -0.12 & -0.02 & 0.06 & -0.08 & -0.09 \\
RIW-8 & 117 & $0.61^{* *}$ & $0.68^{* *}$ & -0.13 & 0.05 & -0.05 & 0.12 & 0.14 \\
SUL-9 & 203 & $0.67^{* *}$ & $0.67^{* *}$ & -0.03 & 0.13 & 0.02 & 0.10 & 0.10 \\
\hline
\end{tabular}

${ }^{1}$ Number of eggs laid to 150 th day of age. ${ }^{2}$ Number of eggs laid from 151st to 175 th day of age. ${ }^{3}$ Average egg weight 222 nd day of age. ${ }^{*} P<0.05, \quad{ }^{*} P<0.01$

The relationships existing between egg weight on one hand and number of eggs laid in the beginning of laying period, number of hatching and unfertilized eggs, number of hatched chicks, and hatchability on the other are presented in Table 3. Mostly negative phenotypic correlations existed between egg weight and number of eggs laid till the 150th 
day of age and ranged from $r_{p}=-0.34$ to $r_{p}=0.08$. A negative correlation $r_{p}=-0.34$ calculated for the line RIW- 8 was statistically highly significant $(P<0.01)$. Negative correlations existed between egg weight and number of hatching eggs per hen and ranging from $r_{p}=-0.23\left(P<0.05\right.$; line BPR-1) and $r_{p}=-0.21 \quad(P<0.01 ; B P R-3)$. The relationship existing between the egg weight and the number of hatched chicks per hen is rather interesting due to calculated negative to zero correlation ranging from $r_{p}=-0.19(P<0.01 ; B P R-3)$ to $r_{p}=0.02$. Similarly, correlations existing between the egg weight and hatchability were always negative and their values ranged from $r_{p}=-0.15\left(P<0.05 ;\right.$ SUL-9) to $r_{p}=-0.04$. Negative correlations existing between the egg weight and the number of unfertilized eggs/hen and the egg weight and hatchability correspond with results published by HARTMANN et al. (2002). In contrast, we cannot corroborate the data published by WILSON (1991) who found out that the hatchability of eggs of intermediate size was better than that of very large and/or very small eggs. According to the results mentioned above, following conclusion can be made for all studied lines: the eggs with lower weight showed a better hatchability. Regarding the concurrent selection for an increased egg weight it can be concluded that this preference of smaller eggs is really counterproductive. This result is in accordance with finding concerning decreased hatchability of larger eggs with lower egg white ratio and higher yolk ratio (MÁCHAL et al. 1992).

Table 3

Estimation of correlation coefficient between egg weight and numberlaid eggs in beginning of egg laying, number of hatching and unfertilized eggs, hatched chicks and hatchability

Korrelationskoeffizienten zwischen den Eigewichten und den erfassten Merkmalen

\begin{tabular}{lccccccc}
\hline Line & $\mathrm{n}$ & $\begin{array}{c}\text { Eggs } \\
1-150 \mathrm{~d}^{1}\end{array}$ & $\begin{array}{c}\text { Eggs } \\
151-175 \mathrm{~d}^{2}\end{array}$ & $\begin{array}{c}\text { Hatching } \\
\text { eggs/hen }\end{array}$ & $\begin{array}{c}\text { Unfertilized } \\
\text { eggs/hen }\end{array}$ & $\begin{array}{c}\text { Hatched } \\
\text { chicks/hen }\end{array}$ & Hatchability \\
\hline BPR-1 & 100 & 0.04 & $0.29^{*}$ & $-0.23^{*}$ & -0.05 & -0.10 & -0.07 \\
BPR-2 & 251 & 0.08 & $-0.26^{*}$ & 0.03 & 0.07 & -0.08 & -0.11 \\
BPR-3 & 216 & -0.05 & $0.21^{* *}$ & $-0.21^{* *}$ & 0.03 & $-0.19^{* *}$ & -0.12 \\
RIR-4 & 185 & -0.09 & -0.03 & 0.10 & 0.00 & 0.02 & -0.05 \\
RIR-5 & 79 & -0.05 & -0.10 & 0.04 & 0.06 & -0.11 & -0.15 \\
RIR-6 & 106 & -0.09 & -0.10 & -0.04 & -0.04 & -0.11 & -0.04 \\
RIR-7 & 112 & -0.14 & 0.11 & 0.15 & -0.09 & 0.01 & -0.07 \\
RIW-8 & 117 & $-0.34^{* *}$ & -0.03 & -0.06 & -0.11 & -0.11 & -0.10 \\
SUL-9 & 203 & -0.07 & -0.06 & -0.05 & 0.02 & -0.13 & $-0.15^{*}$ \\
\hline
\end{tabular}

${ }^{1}$ Eggs laid to 150 th day of age. ${ }^{2}$ Eggs laid from 151 st to 175 th day of age. $\quad{ }^{*} P<0.05, \quad{ }^{*} P<0.01$

The relationship between the number of hatching eggs/hen and the hatchability of hatching eggs in the initial laying lines is quantified in Table 4. This relationship is mostly positive and the calculated values of correlation coefficients ranged from $r_{p}=-0.02$ to $r_{p}=0.39$. Calculated values of correlation coefficient were positive and statistically highly significant $(P<0.01)$ in all three BPR lines $\left(r_{p}=0.21,0.32,0.39\right.$, respectively), in the line RIR-7 $\left(r_{p}=0.24\right)$, and in the line RIW-8 $\left(r_{p}=0.36\right)$. A positive relationship between the number of hatching eggs/hen and the hatchability was influenced by calculated negative correlations existing between the weight of eggs and the hatchability as well as between the weight of eggs and the number of laid eggs. As far as the hatchability is concerned, it can be concluded that in the aforementioned laying lines those hens are preferred, which 
produce more eggs of smaller size and that this fact obviously influences also the efficiency of selection for a greater weight of produced eggs.

Table 4

Estimation of correlation coefficient between number of hatching eggs/hen and hatchability Korrelationskoeffizienten zwischen Brateizahl/Henne und Schlupfergebnissen

\begin{tabular}{lcc}
\hline Line & $\mathrm{n}$ & Hatchability \\
\hline BPR-1 & 100 & $0.39^{* *}$ \\
BPR-2 & 251 & $0.21^{* *}$ \\
BPR-3 & 216 & $0.32^{* *}$ \\
RIR-4 & 185 & 0.11 \\
RIR-5 & 79 & -0.02 \\
RIR-6 & 106 & -0.02 \\
RIR-7 & 112 & $0.24^{* *}$ \\
RIW-8 & 117 & $0.36^{* *}$ \\
SUL-9 & 203 & 0.07 \\
\hline
\end{tabular}

\section{Acknowledgements}

This study was supported by the project of the Czech Ministry of Education, Youth and Sports - MSM 6215648905.

\section{References}

Durmus I, Atasoglu C, Mizrak C, Ertas S, Kaya M (2004) Effect of increasing zinc concentration in the diets of brown parent stock layers on various production and hatchability traits. Arch Tierz 47, 483-9

Fasenko GM, Hardin RT, Robinson FE, Wilson JL (1992) Relationship of hen age and egg sequence position with fertility, hatchability, viability, and preincubation embryonic-development in broiler breeders. Poultry Sci 71, 1374-83

Fasenko GM, Robinson FE, Danforth BL, Zelter I (2000) An examination of fertility, hatchability, embryo mortality, and chick weight in double versus single-yolked broiler breeder eggs. Can J Anim Sci 80, 489-93

Flock, DK (1995) Changing emphasis in genetic development of egg-type chickens. Arch Tierz 47, 479-88

Hartmann C, Strandberg E, Rydhmer L, Johansson K (2002) Genetic relations between reproduction, chick weight and maternal egg composition in a White Leghorn line. Acta Agr Scand A - An 52, 91-101

Máchal L, Suchý P, Kalová J, Jelínek P (1992) The relationship of hatchability and proportions of yolk, albumin and shell in eggs of hens bred in a cage technology system. Živoč Výr 37, 601-6

Máchal L, Zatloukal M, Jeřábek S, Molnárová Z (2003) The process of embryonic mortality in seven initial laying strains during incubation. ArchTierz 46, 483-9

Mennicken L, Ponsuksilli S, Tholen E, Khang NTK, Steier K, Petersen J, Schellander K, Wimmers K (2005) Divergent selection for omega $3:$ omega 6 polyunsaturated fatty acid ratio in quail eggs. Arch Tierz $48,527-34$

O'Sullivan NP, Dunnington EA, Siegel PB (1991) Relationship among age of dam, egg components, embryo lipid transfer, and hatchability of broiler breeder eggs. Poultry Sci 70, 2180-5

Pedrosso AA, Andrade MA, Café MB, Leandro NSM, Menten JFM, Stringhini JH (2005) Fertility and hatchability of eggs laid in the pullet-to-breeder transition period and in the initial production period. Anim Reprod Sci 90, 355-64

Ruiz J, Lunam CA (2002) Effect of pre-incubation storage conditions on hatchability, chick weight at hatch and hatching time in broiler breeders Brit Poultry Sci 43, 374-83

Seker I, Kul S, Bayraktar M (2005) Effects of storage period and egg weight of Japanese quail eggs on hatching results. Arch Tierz 48, 518-26

Sewalem A, Wilhelmson M (1999) Genetic study of embryonic mortality in hite Leghorn lines selected for production traits. Brit Poultry Sci 40, 467-71 
Swackowski T, Wezyk S, Piotrowski P, Cywa-Benko K (2000) Direct and maternal genetic and environmental effects for fertility and hatchability in laying hens. Arch Geflügelkd 64, 115-20

Tona K, Decuypere E, Coucke W (2001) Effects of strain, hen age and transferring eggs from turning to stationary trays after 15 to 18 days of incubation. Brit Poultry Sci, 42, 663-7

Wilson HR (1991) Interrelationships of egg size, chick size, post-hatching growth and hatchability. World Poultry Sci 47, 5-20

Received 8 October 2008, accepted 16 December 2009.

Corresponding author:

LADISLAV MÁCHAL

email: machal@mendelu.cz

Department of Animal Breeding, Faculty of Agronomy, Mendel University of Agriculture and Forestry in Brno, Zemědělská 1, 61300 Brno, Czech Republic 